\title{
鑄鐵の $\mathrm{A}_{1}$ 變態溫度に及济す諸元素の影響
}

佐川繁 兆*

Shigeya Sagawa: The Influence of Some Elements on the Eutectoid Temperature of Cast Iron. The author carried out the experiments to make clear the infuence of $\mathrm{Al}, \mathrm{Si}$, $\mathrm{Mn}$ and $\mathrm{Cr}$, on the eutectoid temperature of stable and metastable iron-carbon systems.

The effects of these elements are similar to their effects on the graphitization of white cast iron ; i. e., $\mathrm{Si}$ and $\mathrm{Al}$, which promote the graphitization, increase the temperature difference of stable and metastable eutectiods and the effect of $\mathrm{Al}$ is stronger than that of $\mathrm{Si} ; \mathrm{Mn}$ and $\mathrm{Cr}$, on the other hand, disturb the graphitization and so decrease the temperature difference of the two, and the effect of $\mathrm{Cr}$ is stronger than that of $\mathrm{Mn}$.

(Received December 13, 1950)

\section{I. 緒 害}

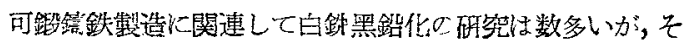
の大部分は共晶及が初析セメンタイトを黑鉛化せしめる第 1 段及び，共析セメンタイトを黑鉛化せしめる第 2 段黑鋁化 に関し，温度と黑鉛化速度及びこれ等沈対する組成の影響が 主服目となつている(1)。最近(2) 第 1 段黑鉛化終了後冷却途

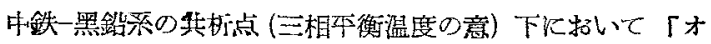

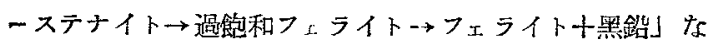
る变化か起ることが䀦らかせられた。組成と冷却速度の 相湋によりオーステナイトがこの反応飞全部消失しないら ち愠度が下ればパーライトを生ずる。これがいわ功る

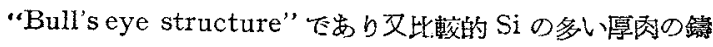
鉄によく見られる地鉄と垚敛とパーライトとの共存組織'E 品る.

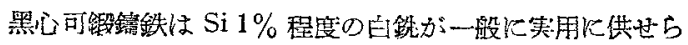
れるが，この程度の Si 㗳度て恃可成り徐冷しない限り後速 する如く，準安定系の区底の方力起りフェライトは生じ難く 地は㕸んどパーライトのみとなる。新㻎諭尤れば「オー ステナイト $\rightarrow$ 過飽和フェライト $\rightarrow$ エライト+黑敛」の方か： 「オーステナイトーパーライト」なる反虑上りも高温河扔

* 東北大学金屬材粦研究所

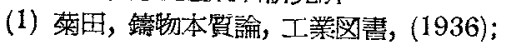
Piwowarsky, Graugussz and die Phisi halishMetallurgishen Grundlagen seiner Heritellung,

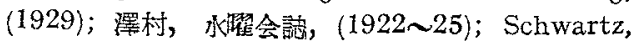
Ruff, T. A. S. M., 25 (1937)；落者, 本声, 13 (1949); 14 (1950), etc.

(2) 青本, 本誌, 11 (1947).
い起るから，前者を筧結せしめ得れば，パーライトを生じ

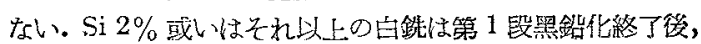

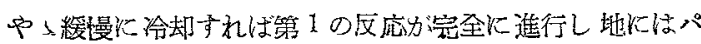

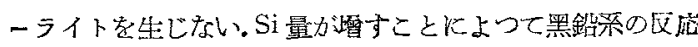
か起り易くなる原因はとれ汇よつて $\mathrm{A}_{1}$ 変態温度が上舁し，

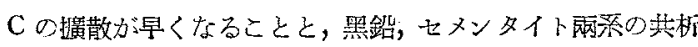
温度差は大となりパーライト系に澾する以前に黑鉛系の反 底力゙完了するためでる。

黑鍇化現象炕対して Si の外に Mn, Cr 等が如何なる影響

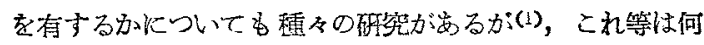

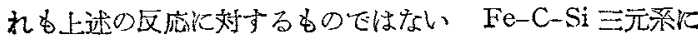
执いては $\mathrm{Fe}-\mathrm{C}$ 系の共析点が $\alpha ， \gamma ， \mathrm{C}$ (黑鋁文はセメンタイ

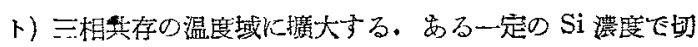

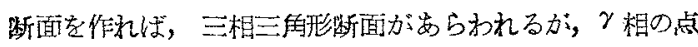

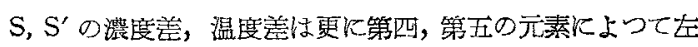

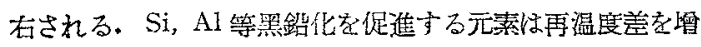
大せしめ，Mn，Cr 等黑鉛化を好等する元素梳状熊図的火は

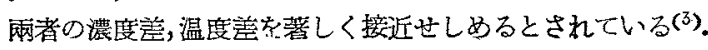
本研究てにはこれ等元素の $A_{1}$ 温度域化扢ける影響を直接実

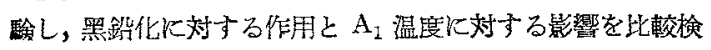
討した.

\section{II. 害 龭}

1. 方針 黑鉛化を促進せしめる $\mathrm{Si}, \mathrm{Al} の \mathrm{~A}_{1}$ 温受域

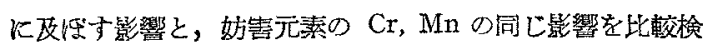
馀する. 但し $\mathrm{Fe}-\mathrm{C}$ 二元采に対して $\mathrm{Cr}, \mathrm{Mn}$ の作用は見難

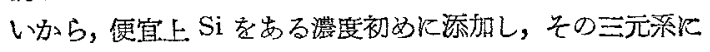

(3) Alloys of Iron Research Monograph Series: $\mathrm{Fe}-\mathrm{C}, \mathrm{Fe}-\mathrm{Mn}, \mathrm{Fe}-\mathrm{Cr}, \mathrm{Fe}-\mathrm{Si}$ etc. 
詨する $\mathrm{Cr}, \mathrm{Mn} の$ 影響を検討して行くことにした。即ち三 元系犾態図に和いて $\mathrm{Si}$ 一定整度の断面についてその $\mathrm{A}_{1}$ 域 がこれ等第三元素によつて如何に䈍響されるかを検訶する わけだる。

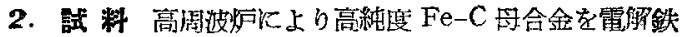
と電極炭素とより橴製し，乙れに金屬 $\mathrm{Si}, \mathrm{Mn}, \mathrm{Cr}, \mathrm{Al}$ 等を 合金せしめて Table 1 の如き試料を作つた。試片は $6 \mathrm{~mm}$ $\phi の$ 金型鑄造の刍銑である。

Table 1

\begin{tabular}{|c|c|c|c|c|c|c|c|}
\hline \multirow{2}{*}{$\begin{array}{l}\text { Spec. } \\
\text { No. }\end{array}$} & \multicolumn{7}{|c|}{ Compositions of Specimens } \\
\hline & C & $\mathrm{Si}$ & Mn & $\mathrm{P}$ & $\mathrm{S}$ & $\mathrm{Al}$ & $\mathrm{Cr}$ \\
\hline $\begin{array}{l}\text { S-1 } \\
\text { S-2 } \\
\text { S-3 }\end{array}$ & $\begin{array}{l}3.01 \\
3.03 \\
2.95\end{array}$ & $\begin{array}{l}1.18 \\
1.89 \\
2.83\end{array}$ & $\begin{array}{l}0.813 \\
0.012 \\
0.012\end{array}$ & $\begin{array}{l}0.010 \\
0 . \overline{016}\end{array}$ & $\begin{array}{l}0 . \overline{027} \\
0.031\end{array}$ & $=$ & 二 \\
\hline $\begin{array}{l}\mathrm{A}-1 \\
\mathrm{~A}-2 \\
\mathrm{~A}-3\end{array}$ & $\begin{array}{l}\overline{3.24} \\
2.95\end{array}$ & $\begin{array}{l}0.019 \\
\overline{0.12}\end{array}$ & $\overline{0.23}$ & $\overline{0.009}$ & $0 . \overline{026}$ & $\begin{array}{l}0.78 \\
2.01 \\
2.95\end{array}$ & E \\
\hline $\begin{array}{l}M-11 \\
M-12 \\
M-13 \\
M-14\end{array}$ & $\begin{array}{l}3.01 \\
3.04 \\
3.09 \\
3.01\end{array}$ & $\begin{array}{l}1.23 \\
1.11 \\
1.22 \\
1.24\end{array}$ & $\begin{array}{l}0.34 \\
0.81 \\
1.42 \\
1.74\end{array}$ & $\begin{array}{l}0.003 \\
\underset{0.009}{\longrightarrow}\end{array}$ & $\begin{array}{c}0.028 \\
\overline{0.026} \\
-\end{array}$ & $\overline{-}$ & E \\
\hline $\begin{array}{l}\mathrm{M}-21 \\
\mathrm{M}-22 \\
\mathrm{M}-23 \\
\mathrm{M}-24 \\
\mathrm{M}-25 \\
\mathrm{M}-26\end{array}$ & $\begin{array}{l}3.00 \\
3.02 \\
3.07 \\
2.93 \\
2.96 \\
2.87\end{array}$ & $\begin{array}{l}2.06 \\
2.08 \\
2.07 \\
2.31 \\
1.94 \\
2.27\end{array}$ & $\begin{array}{l}0.24 \\
0.52 \\
0.86 \\
1.30 \\
1.73 \\
2.90\end{array}$ & $\begin{array}{c}0.009 \\
-\overline{0.027} \\
\overline{0.027}\end{array}$ & $\begin{array}{c}0.036 \\
- \\
0.023 \\
-\end{array}$ & $\begin{array}{l}- \\
- \\
-\end{array}$ & - \\
\hline $\begin{array}{l}\mathrm{M}-31 \\
\mathrm{M}-32 \\
\mathrm{M}-33 \\
\mathrm{M}-34 \\
\mathrm{M}-35\end{array}$ & $\begin{array}{l}2.90 \\
3.02 \\
2.76 \\
2.75 \\
3.28\end{array}$ & $\begin{array}{l}2.88 \\
2.99 \\
3.21 \\
3.23 \\
3.21\end{array}$ & $\begin{array}{l}0.54 \\
0.75 \\
1.25 \\
1.90 \\
2.10\end{array}$ & $\begin{array}{l}\text { trace } \\
\overline{0.011} \\
\overline{0.010}\end{array}$ & $\begin{array}{l}0.026 \\
\overline{0.025} \\
0.028\end{array}$ & 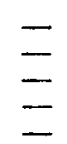 & $=$ \\
\hline $\begin{array}{l}\mathrm{C}-11 \\
\mathrm{C}-12\end{array}$ & $\begin{array}{l}2.95 \\
3.00\end{array}$ & $\begin{array}{l}1.47 \\
1.21\end{array}$ & $\begin{array}{c}0.037 \\
-\end{array}$ & $\begin{array}{c}0.010 \\
-\end{array}$ & $\underline{0.031}$ & - & $\begin{array}{l}0.43 \\
1.04\end{array}$ \\
\hline $\begin{array}{l}\mathrm{C}-21 \\
\mathrm{C}-22 \\
\mathrm{C}-23\end{array}$ & $\overline{3.04}$ & $\begin{array}{l}2.40 \\
2.37 \\
2.36\end{array}$ & $\begin{array}{l}0.009 \\
-\end{array}$ & $0 . \overline{009}$ & $\overline{0.032}$ & $=$ & $\begin{array}{l}0.36 \\
0.49 \\
0.86\end{array}$ \\
\hline $\begin{array}{l}\mathrm{C}-31 \\
\mathrm{C}-32 \\
\mathrm{C}-33\end{array}$ & $\begin{array}{l}3.04 \\
- \\
-\end{array}$ & $\frac{2.93}{2.97}$ & $\begin{array}{l}0.0032 \\
0.0034 \\
-\end{array}$ & 0.023 & $\overline{0.012}$ & E & $\begin{array}{l}0.44 \\
0.78 \\
1.46\end{array}$ \\
\hline $\begin{array}{l}\text { Spec. } \\
\text { No } \\
\text { Com- } \\
\text { pn } \%\end{array}$ & C & Si & $\mathrm{Mn}$ & $\mathrm{P}$ & $\mathrm{S}$ & $\mathrm{Al}$ & $\mathrm{Cr}$ \\
\hline
\end{tabular}
域に入るから，安定哥たは地にはこの三相を一 定比生じ，㭙間の経過によつてもこの比に效化

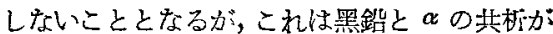
起るとした場合だるがしの共朴は起り難い。 黑鉛共析紀織はまだ発見されていないから共析 は起らぬと仮定すれば（以下同粎に仮定する） $\gamma$

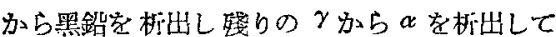
との三相となる・一方セメンタイト系をは地は

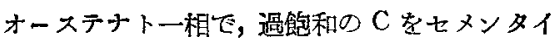
トの形で机出してくる. 特炕 Cr, Mn が多くな い跟りセメンタイト杀のみが起ることは殆んど なく，ある程度長时閪のオーステンパーによつ て陚料は安定系に榇るから才ーステナイトから フュライトを生じ，眠析出のセメンタイトはオ ースデナイト化とけこむ。從つて $\gamma ＼alpha$ ，照鉛， セメンタイトの混合物のときるあり得るし，せ

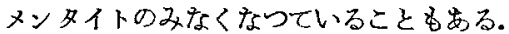

(b) の場合も全く同㥞厄何れにせよこの温度 ではパーライトは生じていない。

(4) $\mathrm{T}_{4}$ (a) 安定系D $\mathrm{A}_{1}$ 変態以下であるから

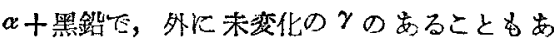
る. 準安定䅫では「オーステナイト十セメンタ イト」域で安定，準安定何れ反從つてもパーラ イトを生じない.

(b) 黑鉛采に拈いては (3)の (a) と全く同様 で女る。メンタイト系ては $\gamma, a$ ，七メンタイ 卜（パーライト）共存域に相当する。初めから妿 定而の変化をすればパーライトはまらわれてな

3. 實 驗 上副の試料を第 1 段黑鉛化せしめ，レーデブ ライトセメンタイトを完全に消失せしめる、これを备 $2 \sim 3 \mathrm{~cm}$

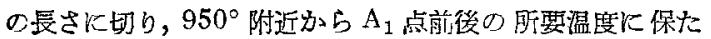

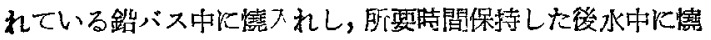
入れして紀織を検鏡した。

\section{III.}

1. 組織變化の教察 結果の解释にあたつてオーステン パーによつて起り得る組織変化を状態図の上から考察して

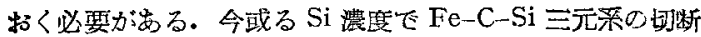
面を作れば，Si 漟度如何によつては Fig. 1 の (a) 又は (b) の上弓に $\alpha, \gamma$ ，㫮鉆三柜域とオーステナイトーパーライ 卜共存域とか漓倠れる場合と雷なる場合とがある。 Si，Al等 黑鉛化促進元蒵は (a) の上引Kなり，Mn，Cr 等は (b) の上

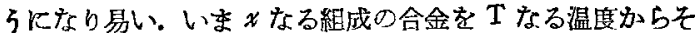

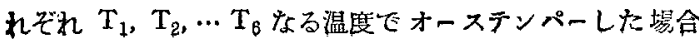

いが、初めKセメンタイト䇣の变化をすればオーステナイト とパーライトとが一定比て其存することKたる. 又 ES 面炕 付して過冾する埸合も考えられるが，このときは地は全部才 ーステナイトで墨鉛入はセメンタイトを析出してくる．安 定系の变化以外は何れる平衡状態ではないか，引続き滦化 を起して安定系に行く可能性がある・パーライトを生じた 場合はパーライトが黑鍇化を起して安定禾の平衡火達する か，安定形怯三相共存城なる叻之本衛火相当する $\alpha, \gamma$ ，黑 鉛を出して本衡することになる。

(5) (a)，(b) 安定乔については $A_{1}$ 㸚熊以下であり，女

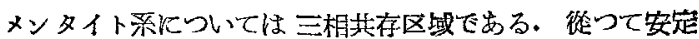
系の装化をするときは地はフェライトのみとなり，セメンが イト䒺の変化を゙るときは，オーステナイトとパーライトと が一定比て共存する。この場合パーライトか黑鉛化を起し， 安定平衡に移行すれば勿論フ、ライトのみとなる，又オー 
ステナイトか過冾されるとすれば $\boldsymbol{\alpha}, \gamma$ 共存状態をへてフェ ライトのみの状態移行する。奏卧的にはオーステナイト

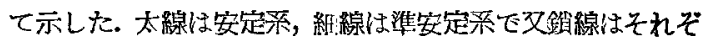
れの区応の開始する温度, 実線は終了温度である。これ等の (a)

Fig. 1 Sectional Diagrams of Fe-C-Si System by a Cnstant Si-per cent.

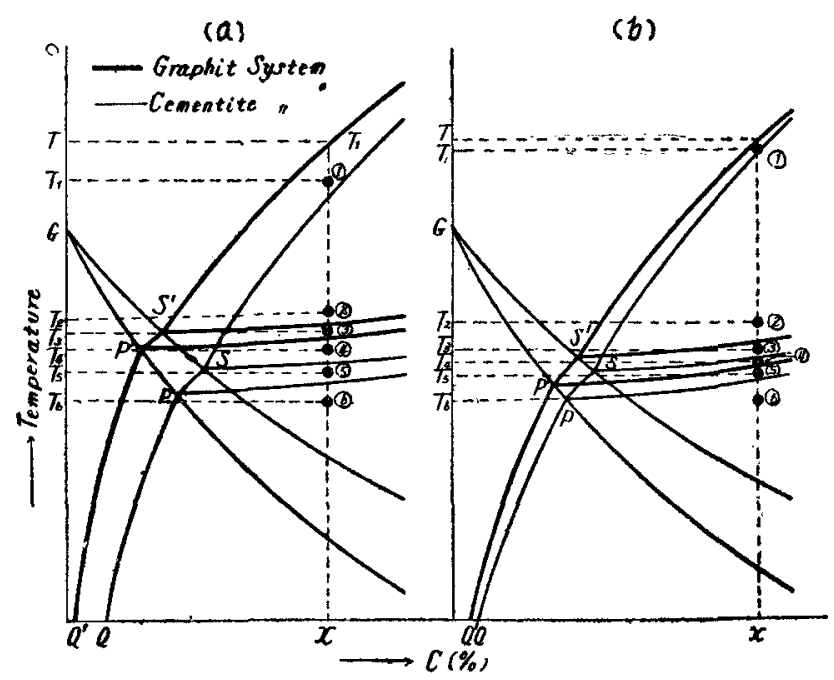

とパーライト其存状熊からパーライトが黑鉆化してフェラ イトの2の状態移行卞るのが見られ過冷されるのは見ら れケい. 的してパーライトを生ずる变化はフェライトを生 ずるものより起り易い.

(6) (a)，(b) 安定采につ小多準安定系について $\mathrm{A}_{1}$

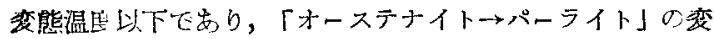
化力゙行まれる。

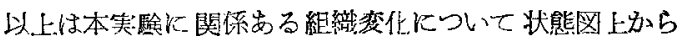

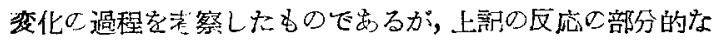

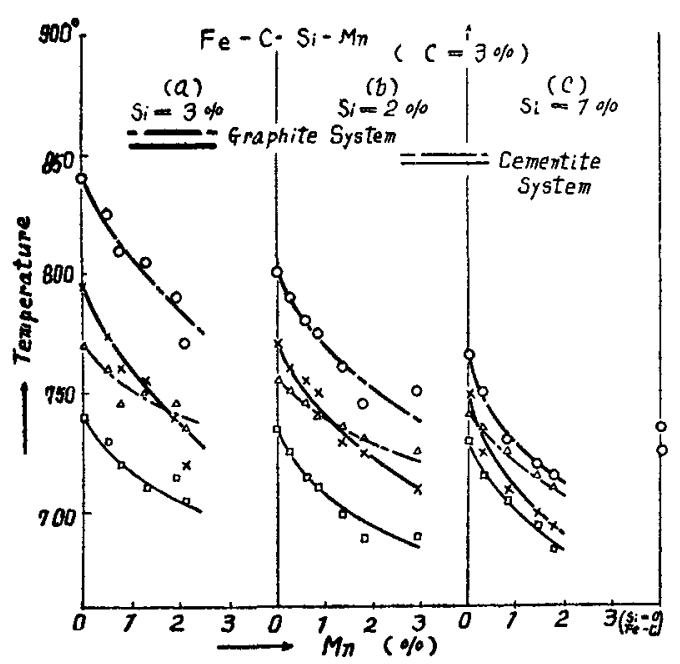

Fig. 3 Change of the Eutectoid Temperatures by the Composition.

進行や反応速度の大小等によつて得られる組織はいるいる になる. 然し制定の基準は上腒の如くに考えられる.

2. 菑娩結果 Fig. 2〜4Kそれぞれの場合を一括し

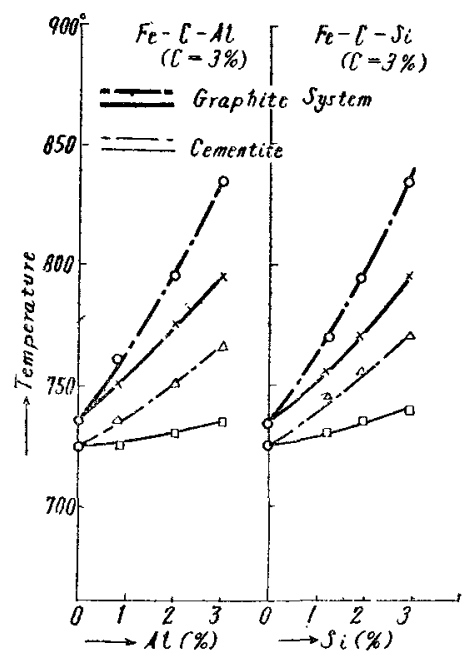

Fig. 2 Change of the Eutectoid Temperatures by the Composition.

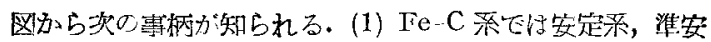

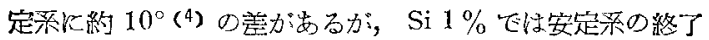

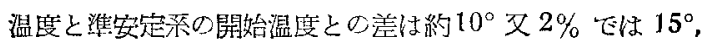
$8 \%$ 厄は 25 Kなる。一方A1 の場合はこの善か：Si の坦合 上りも著しく, Al 1\% 厄は 15，2\% 厄は $20^{\circ}, 3 \%$ では $30^{\circ}$ でる. (2) Fe-C-Si K Mn, Cr 添加の影響をみれば それぞれ Fig. 3，4のよ5な結果になる。即ら (3) Mn が入

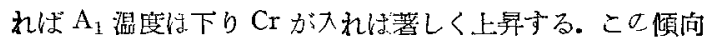

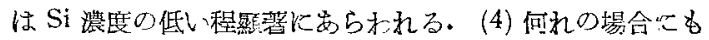

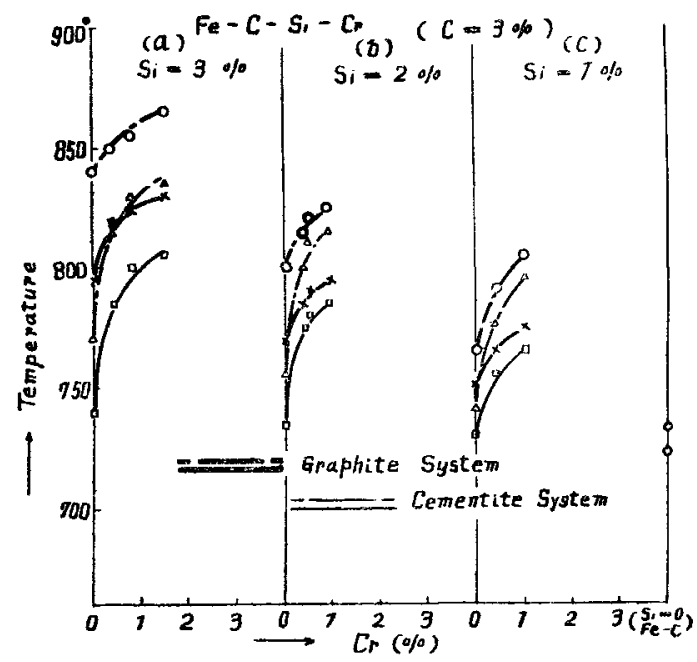

Fig. 4 Change of the Eutectoid Temperatures by the Compoition.

$\mathrm{Si}$ ，一定の場合には Mn，Cr が多くなる程 $\mathrm{A}_{1}$ 温度の降下又

(4) Epst-in, Alloys of Iron and Carbon. 1 (1936), 157. 


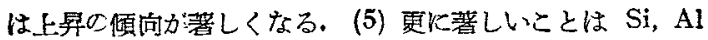

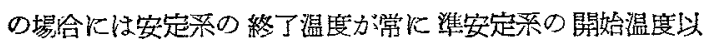
下になつているが (Fig. 2)，Mn，Cr の埸会にはこの籍圍の

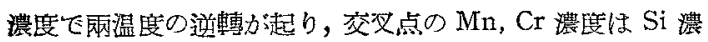

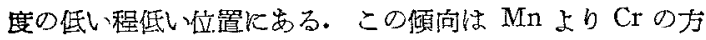

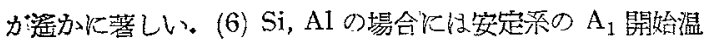
度と準安定添のそれとの温度差はこれ等元素の量と共に埥 大するが， Mn，Cr か添加されると Si 备灙度に和いてこれ 等添加元素の量と共炍逆に減少し，その減少量は Cr の埸合

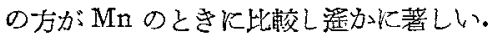

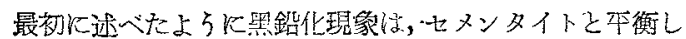
ているC 婊度の高いオーステナイト域办ら黑鈶と平衡して いるC 濃度の焦いオーステナイト域にCが擴散し，黑鍇を 析出して行く現象厄方，從つてある温度に和ける黑鉛系，

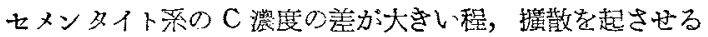
C 濃度公配が大となり，解つて黑鉛化は進行し易くなる。 の晃址から本実験の綕果を見れば交献に見られるA1, Si の
安定禾の $A_{1}$ 落熊温度域內儿相当し，大体この温度に 40 分 保持した時のフェライトの状態と闰じでめb、 $\alpha-\gamma$ - 黑鉛厄 三相本衡力娍立している. Phot. 2 は試料 M 34，740 に80分保持した後我中冷却したものであり，地は大部分フ エライトになつて括り約 30\%のマルテンサイトと約 $10 \%$ のパーライトが散在している。この試料には 3 分たは完全 にマルサンサイトであるが，6分では地にパーライトの島を

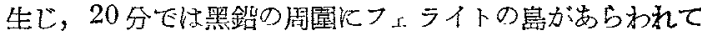
くる.40分で〉ェライトの部分加摭大しパーライトはや 队㳦少与る. 240 分たはパーライトは海失しマルテンサイ

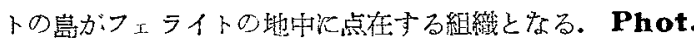
3 は試数 C 21 厄 $780^{\circ}$ から水中に泠却した外のた，地は マルテンサイトヒパーライトの島が点在している、これは 240 分保持㷋の試料であるが，60 分頃がらパーライト量は

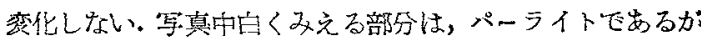

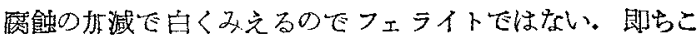
れは準安定系の $\alpha, \gamma$ ，セメンタイト却䒚域厄ある。

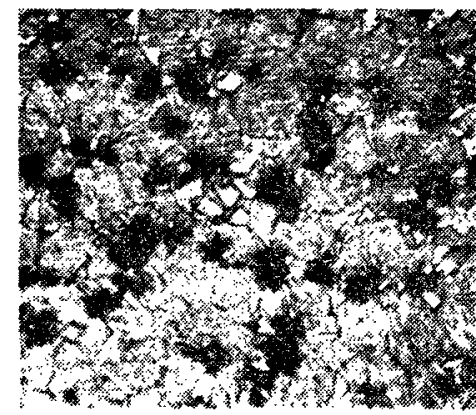

$\times 300$

Photo. No. 1. Spec. C- 31. Mart. + Ferrik-Patch. $800^{\circ}$

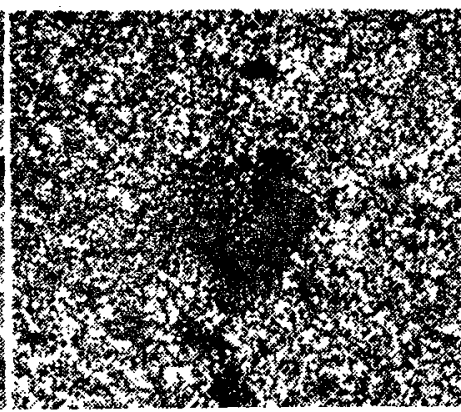

$\times 100 \pi$

Photo. No. 2 Spec. M-34 Mart (Grey) +Ferr. (Matrix) + P. (dark grey) $740^{\circ}$

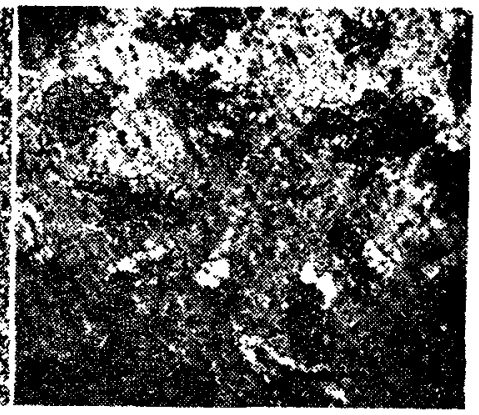

$\times 100$

Photo. No. 3. Spec C- 21 Mart. +p. $\left(780^{\circ}\right)$

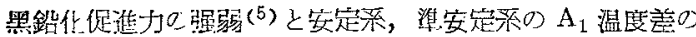

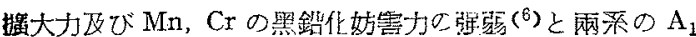
温庋差の縮少力の强弱とはよく一致した結果になつている.

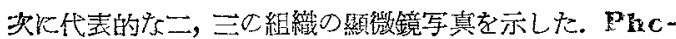
to. 1 試料 C-31厄 $800^{\circ}$ K 240 分保持した後小中

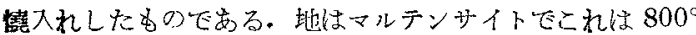
をはオーステナイトを患つた部分，由い片状はフェライトを

(5) 著者, 本誌, 13 (1949).

(6) 菊田, loc. cit; 澤村, loc. cit; Schwartz, Ruff, loc. cit.
V. 結譣

オーステンパー洗により $\mathrm{Fe}-\mathrm{C}$ 杀の共机湽度に改ばす Si

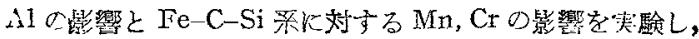

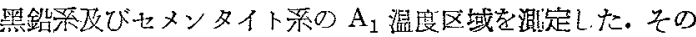

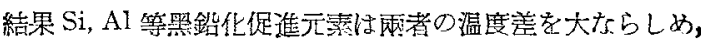

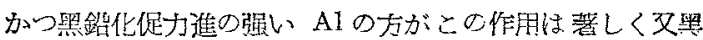

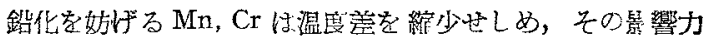

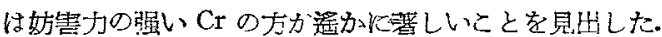

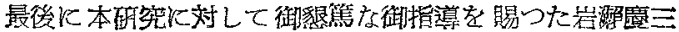

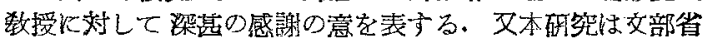

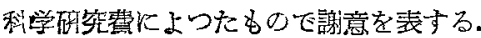

